\title{
Organising migrant workers: the living wage campaign at the University of East London
}

\author{
Dr Ana Lopes* and Dr Timothy Hall*
}

Abstract

This critical case study looks at the campaign led by Citizens UK and Unison to get the University of East London (UEL) to sign up to the London Living wage (LLW). UEL agreed to pay the LLW after a brief campaign in November 2010 and it was subsequently implemented in August 2011. The study charts the course of the campaign and draws on mobilisation theory and new primary research to account for its success. What our findings suggest is that community organisers and union activists were able to organise and mobilise a largely apolitical group of migrant workers. This, we suggest, can be explained by the successful mobilisation of the community and augurs well for future broad-based campaigns.

Key words: living wage, community organising, mobilisation, migrant workers, community unionism. 


\section{Introduction}

What opportunities present themselves, today, for organising migrant workers on issues of pay and working conditions? What forms should this organisation take and what prospects of success do such campaigns have? While these questions are not especially new they are nonetheless timely and urgent. Migrant workers represent some of the most vulnerable and least protected groups of workers in the UK. According to the report of the Commission on Vulnerable Employment (2008, p.12) migrant workers are disproportionately represented in vulnerable employment: more likely to suffer problems at work and summary dismissal; less likely to be members of trade unions and therefore be in a position to have their rights and conditions covered by collective bargaining; less likely to know their employment rights; and more likely to be subject to routine bullying in the workplace. In addition, recent studies have shown that these problems are compounded by recent cuts in public spending in the UK (Rogers et al., 2009). All of this would suggest that the circumstances could hardly be less promising for organising migrant workers. All the more striking, then, that we should see a proliferation of living wage campaigns led by citizens' organisations, trade unions, civic engagement groups and political parties. At present there are living wage campaigns up and running throughout the UK, led by community organisations like Citizens UK; trade unions such as Unison, Unite and the newly formed Independent Workers of Great Britain Union (IWGBU); and organisations within political parties like the Movement for Change in the Labour Party.

Our aim in this paper is to explore these questions by drawing on our experience as participants in the campaign to implement the London living wage at the University of East London (UEL) and original empirical work carried out subsequently with cleaning workers at the University. The campaign to introduce the London living wage at UEL commenced in April 2010. It was led by The East London Communities Organisation (TELCO), the founding chapter of Citizens UK, and formed part of their broader campaign to target the higher education sector in London for living wage campaigns. This campaign achieved striking gains in a relatively short period of time with Queen Mary, The University of London (QMUL), The School of Oriental and African Studies (SOAS), The London School of Economics (LSE), Birkbeck College, the Institute of Education and Goldsmiths College all agreeing to implement the living wage between 2006 and 2010. It is estimated that $£, 4,692,661$ has been redistributed to externally contracted workers in these campaigns between 2005 and 2011 in the higher education sector alone (Wills 2013)

While the campaign to introduce the living wage at UEL certainly benefited from being part of a broader and increasingly high profile campaign, those involved were still surprised the speed of 
its success. Within six months of the start of the campaign the Vice Chancellor of the university announced that the university would be implementing the living wage. This was partly due to the fact that governors and senior managers at the university were sympathetic to the aims of the campaign. However the disposition of senior managers and governors does not explain how readily the cleaning workers were able to organise themselves and put their case for the adoption of the living wage. Within weeks of the start of the campaign, leaders from the cleaning workers had emerged and large meetings of cleaning workers were convened at short notice. We try to account for this success by examining the organisational model adopted in the context of mobilization theory (Kelly, 1998). We also analyse the motivations and experience of the cleaning workers that participated in the campaign. While leaders from the cleaning staff emerged in the course of the campaign for the most part they had no strong backgrounds in union activism - indeed quite the opposite in some cases. We compare and contrast the campaign in UEL with other campaigns in the higher education sector and provide further support for the adoption of broad-based, or community-based, approaches to organising migrant workers.

\section{The announcement and implementation of the living wage at UEL}

The living wage campaign at UEL commenced in April 2010 when community organisers from Citizens UK made contact with academic staff at the university. Having ascertained that cleaning staff were paid just above the national minimum wage there followed separate meetings with staff (some of whom were trade union branch officers) and students to try to kick-start a living wage campaign. After contact was made with cleaning workers a campaign team was formed, composed of academics, students, and cleaning workers and regular meetings were convened.

A key addition to the campaign team was the involvement of the UEL branch at Unison in the summer of 2010. It was evident that if the campaign was to produce lasting benefits beyond an increase in pay it was vital that cleaning workers had the opportunity to join an established trade union. The UEL branch of Unison, supported by the Hidden Workforce Project based at Unison central office, ${ }^{1}$ duly reached out to cleaning workers taking them into membership. This afforded cleaning workers some protection in the actions that they took but also gave them access to branch officers who undertook casework on their behalf. The campaign wasn't simply

\footnotetext{
${ }^{1}$ For further details of this project see the following link; http://www.unison.org.uk/hiddenworkforce/pages_view.asp?did=12672
} 
trade union-led; it also involved the wider community. Cleaning workers received the support of local schools and faith groups who were affiliates of TELCO and local religious leaders spoke at rallies organised on the campus and signed the letter to the Vice Chancellor calling on him to implement the living wage at UEL.

Continued pressure from the campaign team for a meeting led to an announcement by the Vice Chancellor in November 2010 that UEL would implement the living wage. The campaign then entered a new phase. After an initial meeting in December 2010 with senior managers at UEL the campaign team wrote a report into the existing contract which found widespread evidence of mismanagement including late and missing payments leaving cleaning staff with insufficient money to live on. These grievances had come to light in campaign meetings but formalising them in a report enabled union representatives to meet with the facilities managers and the cleaning contractor to rectify the problems.

At this point, the campaign aimed to speed up the tendering process (and implementation of the living wage) through the performance of a complaints choir. ${ }^{2}$ A Performance Arts lecturer at UEL proposed the idea of forming a complaints choir at campaign meeting. The first reactions to the idea were mixed. To some, it appeared that singing was an onerous activity that would only add to overstretched workloads. Others questioned what could be achieved through singing. However, some cleaning staff took to the idea and it was agreed that a small group of volunteers would meet up to work on a song. The first choir meeting became a workshop in which cleaning staff verbalised their 'complaints' or main issues. The lyrics incorporated English and Spanish and the process of rehearsing and learning the song became an educational opportunity as many of the cleaning staff involved in the choir had very low levels of English.

Originally, it was intended that the complaints choir, formed solely of UEL cleaning staff, would perform its song outside the building where the University Board of Governors were to meet. This was intended as a 'shaming' exercise. However, as the date approached it became apparent that a significant number of choir participants would not be able to be on the premises at the time of the Governor's meeting - as most juggle several jobs and child caring responsibilities. Instead, footage of the choir practices and interviews with cleaning staff were edited as a three

\footnotetext{
${ }^{2}$ Valituskuoro is a Finnish term that can be translated as 'complaints choir' and it is an expression used to describe situations in which many people complain simultaneously. Finnish artists Tellervo Kalleinen and Oliver Kochta-Kalleinen took the expression literally and put forward the concept of a choir that sung collective complaints. The idea first became a reality in Birmingham in 2005. A local musician turned complaints into a catchy song which volunteers, gathered through leaflets and flyers, practiced and performed. Since then the artists have been invited to start complaints choirs around the world and are happy for the concept to be used anywhere.
} 
minute film. This was posted on YouTube ${ }^{3}$ and had the desired effect of going viral and catching the attention of UEL's Vice-chancellor. While this phase of the campaign was ultimately unsuccessful in persuading senior managers to take the cleaning service back in-house it did succeed in focusing attention on the tendering process and getting the ethical track record of the company pushed up the agenda.

After the commencement of the new contract in August 2011, the UEL branch of Unison, supported by the Hidden Workforce Unit at Unison ran a training course for new members and began the process of identifying and training representatives to enable cleaning staff to address issues themselves as they arise. While this development is still in process the signs are positive that the gains of the campaign can be consolidated in the form of a unionised workforce capable of resolving its own issues and shaping, to some extent, its working practices. At time of writing approximately 60 cleaners had joined the Unison 20 of which attended the induction training in August 2011.

\section{From Mobilisation Theory to Broad-based organising: the community turn in organising}

This paper is concerned with the successful mobilization of a largely apolitical workforce, that is to say, a group of individual workers without a background in trade unionism or any political affiliation. Within the field of industrial relations one of the most important and influential theories developed to explain this process is mobilization theory developed by Kelly (1998). We begin with this and look to extend the theory with recent research on community organisations.

Mobilization theory has its roots in Marxism. It was first developed by social movements theorists Tilly (1974) and McAdam (1988) and brought into the field of industrial relations by Kelly (1998). In a nutshell, mobilization theory seeks to explain 'how individuals are transformed into collective actors willing and able to create and sustain collective organization and to engage in collective action against their employers' (Kelly, 1998, p.38) It understands the sine qua non for collective action to be a sense of injustice or illegitimacy of, for example, an action by management (Kelly, 1998, p.27). The theory then proposes that a number of factors must be present to turn 'a set of individuals with a sense of injustice or illegitimacy' into 'a social group

\footnotetext{
${ }^{3}$ The film can be viewed at the following link: http://www.youtube.com/watch?v= $=\mathrm{y}-\mathrm{aRNW}-\mathrm{Rst} 4$
} 
with a collective interest'. These factors can be summarised as: attribution, social identification and leadership. Firstly, individuals must place blame on a particular agent (attribution). Secondly, they must understand themselves as a distinct group (social identification). Finally, leaders and activists must be present to help shape both attribution and social identification (Kelly, 1998, pp.29-30). According to Kelly the coincidence of these three factors accounts for the recourse to collective action. The significance of Kelly's approach within the field of industrial relations was to shift attention away from collective bargaining structures and institutions and focus instead on social processes analysed in accordance with these factors. It also enabled him to account for a broader mobilisation in the workplace involving both union members and non-members.

Kelly's theory, while drawing on social movement theory, is primarily an account of trade unionled campaigns. What about campaigns led by community organisations or those led by trade unions and community organisations? What features do these campaigns exhibit and do these fit into the analytic framework he sets out? Arguably Kelly's theory, developed before the emergence of community organisations in the UK, is not best placed to comprehend what is distinctive about these as political and organisational forms or the manner in which they mobilize individuals.

The distinctive approach adopted by living wage campaigns led by community organisations is that they are broad based. Broad-based organising, particularly that developed by Saul Alinsky in the US, aims to bring people of otherwise disparate views together on an issue of fundamental importance. As an approach it is not restricted to campaigning for a living wage but can be applied to any attempt to address an identified community problem. In the hands of citizens organisations one typically finds these organisational approaches applied to a range of issues like the lack of affordable housing; unemployment; youth violence, personal debt etc.

The fundamental characteristics of broad-based organising are that it tends to be citizen-initiated and aimed at realising what is perceived to be the common good. By co-ordinating civil society organisations, comprising individuals, to organise on issues that they agree about, the aim is to open up a space in which the nature of the good life, and the necessary support for it, can be debated (Jamoul \& Wills 2008). Solidarity between individuals, within and across institutions, is engendered through the fostering of public relationships - or political friendships - such that individuals know sufficient about each other (their background and motivations) to organise effectively together. For this reason broad-based organising is sometimes referred to as 'relational' organising because its principal modus operandi is the one-to-one meeting between individuals who are also members of associations/institutions. Unlike other campaign groups 
community organisations like Citizens UK devote as much if not more of their resources to capacity building within their member institutions as they do to campaigns (Alinsky 1989, Chambers 2003, Gecan 2002, Ivereigh 2010).

While both community organisations and trade unions practice broad-based organising, living wage campaigns led by citizens' organisations tend to be different in character to those led by trade unions or political parties. For example, while both employ tactics designed to increase tension between campaign group and power-holder, for the former this is always related to a very definite end - establishing a long term relationship with the power-holder. At the risk of oversimplifying where trade union-led campaigns can often take a conflictual form for a share of the collective product, the focus of citizen-led campaigns tends to be on employers and contractors coming to recognise the common good and 'doing the right thing'.

A number of authors including Wills (2008), Holgate (2005) Heery et al.(2012) and Symon and Crawshaw (2009) have acknowledged what might be termed a paradigm shift in organising models. Where traditional models of organising centre on the workplace and the on-going struggle of workers with managers, broad-based organising, it is suggested, centres on the community and the particular space or locale they occupy. For example, the living wage campaign launched by Citizens UK in 2001, was directed at a particular zone - Canary Wharf, the City - rather than any particular sector. The purpose of this was to strengthen communal relations within the worksite and across worksites.

This is not to suggest that broad-based organising represents a complete break with more orthodox forms of class politics. Jane Wills, for example, views living wage campaigns as evidence of the rise of a 'new urban vanguard' (Wills, 2008, p. 455; also quoted by Hearn and Bergos, 2011, p.79). In an important article from 2008 Jane Wills has analysed the role of class in living wage campaigns. Living wage campaigns, she suggests, demand that we dispense with essentialist conceptions of class. What distinguishes the class politics we find in living wage campaigns from 'essentialist' accounts is an emphasis on contingency and a move beyond the restricted site of the workplace to broader considerations of how the surplus is divided in taxation and public spending and the world of investment - property, pensions, insurance and financial speculation:

[t]he experience of cleaners in London suggests how class interests can be mobilised beyond any fixity in the social structure (class is not just about employment relations at the point of production or service) and beyond any dependence on shared interests or common identities arising from work. As such, London's 
cleaners and their supporters raise challenging questions for those on the Left who remain stuck with a traditional model of class and its potential politicisation. (Wills, 2008, p.26)

While Kelly's theory is not cited here it is clear that the shift in focus from workplace to community in the revitalised conception of class politics envisaged by Wills represents a significant departure from both the Marxist premises and the focus on the workplace as the primary site of conflict in mobilisation theory. If living wage campaigns do represent a new form of class politics as Wills contends this battle is enjoined across society rather than the point of production or service alone.

Warren (2009), Snarr (2007), Jamoul and Wills (2008) and Wills et al. (2009) contrast the progressive engagement of faith-based groups byCitizens UK with the standard co-option of these groups by the state. Whereas the former, they suggest, enables faith communities to retain their radical edge by campaigning on issues of social justice - such as affordable housing, a living wage and the regularisation of migrant workers - the latter serves to de-radicalise and co-opt them in community cohesion projects (Jamoul and Wills, 2008, p. 2036, Defilippis et al. 2010). This is particularly the case in the UK where the government introduced a raft of such projects targeted principally at the Muslim community in response to the London bombings in 2005. The successful engagement of faith groups, they suggest, also accounts for the success of the living wage campaign led by Citizens UK. For not only is this campaign able to draw on the public support and involvement of different faith communities but it was also able to reach migrant workers that are disproportionately members of such communities.

Kelly's mobilisation theory is not best placed to account for the mobilisation of the broader community beyond the workplace and the mobilisation of faith groups in particular. However some authors including Holgate (2009) and McBride and Greenwood (2009) Symon and Crawshaw (2009) have looked to account for this development principally within the trade union movement. Community unionism is an approach which advocates that trade unions should reach out to the broader community and make alliances with a range of civil society groups. In part it is a response to the breakdown of collective bargaining and the falling membership of trade unions. The TUC funded the 'Active Unions Active Communities' project in 2008 (Holgate 2013a). Since then all of the major unions have explored this terrain. Unison have appointed a community organiser to work alongside its existing workplace organisers; In 2011 Unite launched Unite Community to reach out to non traditional members (students, the unemployed, non-unionised workers) (Holgate 2013a). 
Despite these developments relations between community organisations and trade unions are often strained. Jane Holgate (2009) has argued that trade unions often find it difficult to connect with broad-based organising groups (especially the religious elements within them) and are critical of their decision-making structures. Trade union activists and leaders feel that community groups should not operate in an area that they perceive as their 'territory' (such as wages, or the creation of workers associations). Conversely, citizen's organisations like Citizens UK find it difficult to understand and adapt to the democratic processes and timetables of unions. However, Holgate suggests that there is very little in the aims and objectives of these two types of organisations that should prevent them from working together and that locally, the relationship between unions and Citizens UK has improved.

In a more recent article with Simms (Holgate and Simms 2010) Holgate appears to question the earlier claim that there is nothing in the aims and objectives of trade unions and community organisations that preclude closer working relations. Larger theoretical differences would appear to be in play. For example the extent to which capitalism can be managed/regulated and its shortcomings mitigated; the role of civil society, the state and supranational institutions in this regulation/mitigation; the role of civil society and the state in the provision of services and the notion of co-production; the role of class in explaining and remedying social injustice etc. While it would be an oversimplification to contrast class-based approaches to organising favoured by trade unions with communitarian approaches adopted by community organisations, the former tend to be favoured by trade unions alongside a suspicion of involvement of civil society organisations in the delivery of services aimed at remedying social injustice. It is these fundamental differences in approach which explains the appropriation of the model of broadbased organising by trade unions without thinking through the ultimate aims and purposes of the model. If one takes the view that relations between labour and capital are fundamentally antagonistic, whether concentrated at the point of production as Kelly maintains or dispersed across the community as Wills (2008) argues, it is difficult to see how a conception of broadbased organising for the common good can be maintained. With fundamentally different valueorientations it seems likely that relations between trade unions and community organisations will continue to be strained and short term in nature. 


\section{Methods}

We use the living wage campaign at UEL as a critical case study. The living wage campaign at UEL is not typical of other campaigns, nor is the migrant cleaning workforce seen as representative of other similar institutions. The case was deliberately selected for analysis because it was a successful campaign and its analysis will enable the factors that contributed to this success to be identified.

In the first stage of the research the cleaning staff population at UEL was surveyed using a small-scale questionnaire, disseminated through supervisors in the workplace. We received 39 responses, which corresponds to a $43 \%$ response rate. The survey included questions about motivations and experience of migration, as well as questions about past and present experience of political activity, social and civic activities and church activities. We wanted to find out the extent of political and social capital of the group involved in the campaign.

In the second stage, the research team conducted eight semi-structured interviews with cleaning staff at UEL (four women and four men). The interviews explored topics covered in the survey in greater detail. Interviews took place either in the work place or in the participant's home and lasted on average 45 minutes. They were conducted in the participant's first language (Portuguese or Spanish) and subsequently translated. All staff interviewed played a significant role in the living wage campaign at UEL. Although all staff approached were happy to take part in the study, on one occasion a participant expressed uneasiness about responding to questions related to immigration.

The research team also engaged in participant observation at several stages of the living wage campaign at UEL. These included meetings, a complaints choir and a weeklong training course delivered by Unison Hidden Workforce Unit. Direct observation was also carried out during a cleaning work shift, in which cleaning staff were followed and informally interviewed as they went about their work routine.

Lastly, a focus group was set up in which the impact of the London living wage on staff's daily lives was discussed with female cleaning staff. We draw to some extent on that data here although the bulk of this will be explored in a future paper. 
The method chosen to analyse the data set was thematic analysis. We found this to be a flexible method of analysis that enabled us to account for the data in a suitably rich and detailed manner. Themes were identified and analysed by the researchers and patterns across the data set were sought. Interview data was coded using NVivo software.

Our positionality as campaign activists - one of us played a pivotal role in the inception of the living wage campaign at UEL and both of us were involved as activists - has influenced our approach to the research and can be seen as a piece of community-engaged research (Handley et al 2010). A partnership between the community and the researchers was built and strengthened throughout the research process. The community partners collaborated in discreet steps of the research such as participant recruitment and data collection. Findings were disseminated to the community prior to write-up and submission of the completed article. Finally, as individuals engaged in the living wage campaign the research that we undertook can itself be viewed as part of the campaign. In other words the activity of researching itself can be viewed as a practice seeking to bring about the change that it is evaluating. This constituting role of research has recently been referred to by Jane Wills as an epistemology of engagement.(Wills 2014).

\section{Data Analysis}

Throughout this research project we came into contact with most of the men and women who clean all of UEL's buildings and make the work of academics and students possible. We met them, mainly, in our shared work place, during breaks or in campaign activities and meetings. We also met some of them in external campaign events and sometimes we conducted interviews in their own homes. We were able to learn about their experience of migration, the reasons that brought them to the UK, as well as what they see as the positive and negative aspects of this experience.

The cleaning staff at UEL are composed, predominantly, of two groups: a Spanish speaking Colombian group and a Portuguese speaking group, mostly from African Portuguese speaking countries. Indeed, $46 \%$ of our questionnaire respondents originate from the African continent and 30\% from Latin America. The majority of workers who responded to our questionnaire are female, although the male respondents are a significantly large minority (41\%). The age of our 
respondents varies between 18 and 61 with an average of 39. Among the respondents of our questionnaire, the average time spent in the UK is seven years. Forty nine percent of the respondents had been in the UK for less than five years and 27\% between 11 and 20 years.

\section{i. 'Too much work: not enough money'}

In compiling the report into working conditions prior to the introduction of the living wage our questionnaire revealed what cleaning staff perceived as the central problems: late or missing payments, high workload for the number of paid hours (See table below). Our survey revealed that $62 \%$ cleaning workers have experienced late or missing payments. As $65 \%$ do not work for another employer this must necessarily have a significant impact on their quality of life. Moreover, $70 \%$ of survey respondents identified high workloads and limited hours as key problems. The 'deep clean' operation in the halls of residence attracted particular criticism because workers were paid a fixed amount for a set number of rooms. As it was difficult to complete a room in the allocated time levels of pay fell effectively to under $f^{5}$ per hour. A combination of factors, including erratic and low pay, contributed to low levels of retention. A supervisor told us:

Before there were many of us but few of us are still here and we tend to look for something else, to look for another job. All is changing. If you look around (...) many cleaners are new.

As staff leave - and while new staff are recruited and trained - the burden of additional work falls on staff that remain, leading to an increase in their workloads. $40 \%$ of respondents identified the absence of sick pay as a major problem with their work. Cleaning workers are faced with the choice of using up their statutory holiday leave, talking unauthorised leave and losing a day's pay, or working sick.

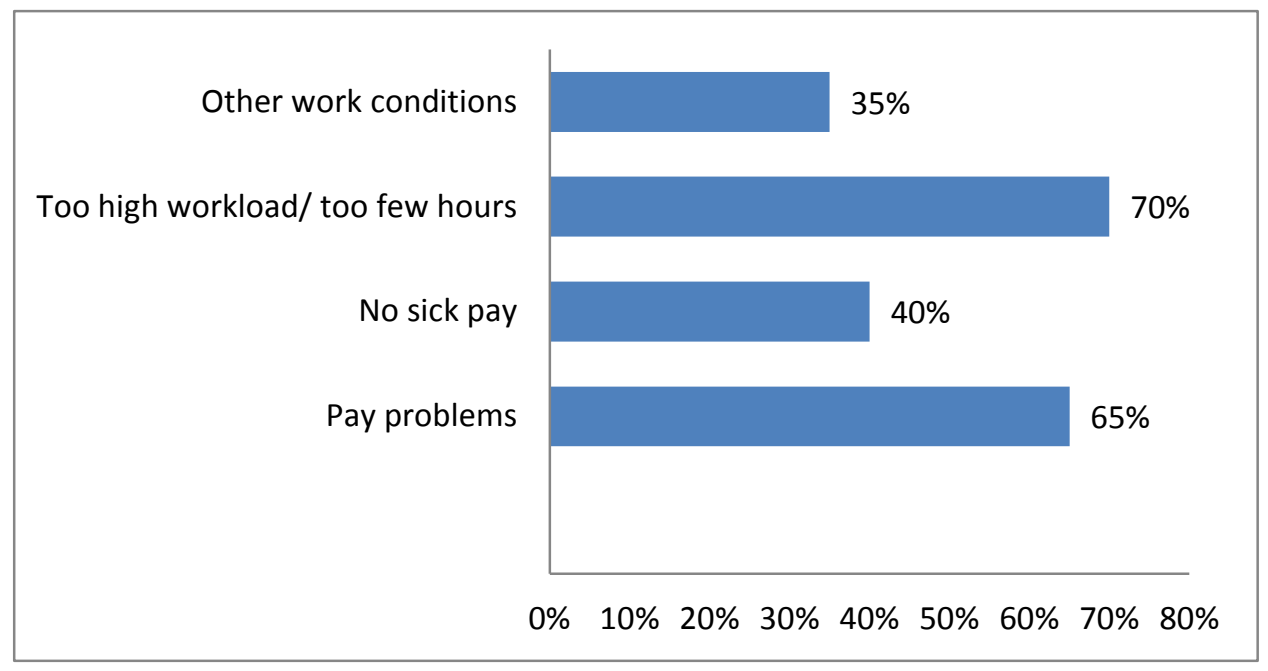


$\mathrm{n}=41$

Fig.1: Main problems at work

\title{
ii. Organising for a living wage
}

As mentioned above, academic staff and other organisers involved in the campaign were surprised by the ease and swiftness with which cleaning staff were able to organise and mobilise in order to participate in meetings en masse and take part in other campaign activities.

A Santomean worker explained why she thought it was important to take part in the initial campaign meetings:

I thought those meetings were important when I realised that [cleaning company] had payment problems; it hadn't happened to me, but I saw my colleagues complaining a lot; I realised that if it happened with them it could also happen with me. That's when I thought it was important to take part.

Another worker explained why she had never joined a union before but felt it was time to do so, as specific problems are being experienced and there is a perceived lack of response from management:

\begin{abstract}
We only need a union when - how can I put this - when there are problems with payments, or similarly specific problems. Then we aren't able to solve them. When we speak to them [the managers] they just send us away. Then what can we do? We can talk to the union and put it in their hands and they will help us solve these problems.
\end{abstract}

The role of emerging leaders is clear from our interviews. Supervisors played a key role, particularly during the initial stages of the campaign, by encouraging cleaning staff to attend campaign meetings. When asked how she first heard about the living wage campaign, a female worker explained:

Actually it was my supervisor, Alex. Yes. He was my supervisor back then; now it's someone else. And so he always said, look there is going to be a union meeting; when you finish work go there. And every time he told me, I went. Then there was a time when we used to set up another one at the meeting itself and so he didn't need to tell me because I already knew.

iii. 'This happened because we did it!' 
Our interviews also revealed how the living wage campaign at UEL impacted on the working lives of cleaning staff. Unsurprisingly, the pay rise that followed the Vice-Chancellor's agreement to pay the cleaning staff the London Living wage comes out in our interviews as the most significant result in the campaign. However, it is clear that this pay rise is not the only benefit resulting from the campaign. Improvements in working conditions, including better treatment by management, are also pointed out as noteworthy. As Margarita put it: 'Things are getting better. The treatment we get is better because of the campaign.' Moreover, besides pay and conditions, participation in the living wage campaign at UEL resulted in empowerment and political awareness for those who took part in it. In the words of a supervisor from Colombia: 'We are all really happy; $[. .$.$] because we know about the rights we have at work, which we didn't know$ before.' When asked what the most important achievement of the campaign had been, a Dominican worker responded: 'Respect. Respect for us, workers. [...] I feel more confident'. She also described the sense of pride that resulted from having played a part in the campaign:

Sometimes one gets tired and says to oneself: I'm not going to do anything. But when you see the results [of the campaign] one feels moved; Then one can say: This happened because we did this.

\section{iv. Social and Political capital}

Faced with such levels of participation and commitment, we expected our interviews to reveal high levels of political capital among our respondents. However, contrary to what we expected, our interviews revealed very low levels of previous political activity among cleaning staff in general and even among the staff who were crucial in making the living wage campaign at UEL possible. Similarly, out of 39 questionnaire respondents, only six had previously been members of trade unions. Of these, only three held posts in a trade union prior to involvement in the living wage campaign at UEL. While this is not an insignificant percentage (15\%) those with trade union experience did not necessarily take prominent positions in the campaign.

We found that, for many of the cleaners, justification for joining the campaign was on the basis of a sense of justice rather than on previous political experience. As a supervisor explained:

\footnotetext{
No, to be honest I didn't have any [experience of political campaigns]. But I always think about what is fair. I don't think what goes on here is fair. A few get rich and we have to do the work - and if we don't like it we can leave, because there are so many more waiting to get a job. That's what led me to become involved really.
}

Association membership, either past or present, is very low. Some cleaning staff did come into contact with migrant associations, typically soon after their arrival in the UK. This has mostly 
been in order to get legal advice and support. Most are aware of the existence of such groups and associations and the kind of support they can provide. Only one of our interviewees is actively engaged in one such association and is undergoing telephone helpline training to act as a volunteer. On the contrary, church attendance and participation in faith organisations came up as significantly high among our respondents. Twenty-six questionnaire respondents indicated attending church regularly and our interviews revealed significant levels of participation in faithbased-groups and activities. Interviewees often described faith-based groups as privileged sources of support, especially for the solution of practical problems and the provision of information. As a Colombian worker explained:

\footnotetext{
When I brought my daughters over, a Christian organization helped me to resolve some problems, like housing. This organization does not exist anymore because of government cuts, but I still like going to church.
}

Our interviews suggest that church-going and social activities organised by faith groups act as an integrating mechanism and provide opportunities to seek support in their first language. We also found an overlap of membership between the church groups and migrant associations (where they meet the same people in both).

\section{Discussion of Findings}

The case study examined in this paper illustrates the relevance of mobilization theory to explain how a largely apolitical workforce successfully mobilised around the living wage campaign. We found a particular set of factors present that helped to transform perceptions of injustice into concrete collective action. Firstly, a perception of specific problems such as payment problems and work intensification led to a sense of injustice. Secondly, the source of these problems was clearly identified with the cleaning company management. The following excerpt from an interview with one of the cleaning staff exemplifies this attribution:

\footnotetext{
The problem is with those who manage the company at UEL. I believe this is the greatest problem. I don't know what they do... how they organise wage payments. But as far as I understand the company gets a certain number of time sheets, for example, and they pay according to those time sheets. So the company isn't responsible for the mistakes. The ones who are responsible are the ones who manage the company in the different sites, in this case, the university.
} 
Thirdly, social identification occurred as migrant workers. Emerging leaders, initially supervisors, played a key role in promoting and shaping these factors.

Cleaning workers at UEL who were involved in the living wage campaign emerged as a group of migrant workers with little political experience, but with significant associations with faith-based groups. Indeed, religion seems to be a key source of bonding social capital. Religion may also be a source of the staff's pride in their work, as verbalised in some of our interviews - despite stigmatisation and low pay. Seventy percent of the cleaning workers who responded to our questionnaire said they regularly attended a place of worship in contrast to just fifteen percent who said they were previously members of trade unions. It further transpired in the interviews with key leaders that a number attended the same church in east London that specifically catered for the Latin American community in the area. While this church itself was not an affiliate of TELCO, it became clear that the developments at UEL were widely known amongst the congregation.

The literature points to tensions between trades unions and community groups (Holgate, 2009). The living wage campaign at UEL, however, is a good example of community organisations and trade unions working together effectively. In this case Unison activists and Citizens UK organisers were able to come together and utilise each other's strengths to pursue a successful campaign. This confirms Holgate's finding that locally, the relations between these two groups are improving.

Moreover, unionisation of the cleaning workforce at UEL and the activities that followed (such as union training course, ESOL) have meant that the cleaning staff are in a better position to represent themselves and address other problems they may face in the workplace. This concurs with McBride and Greenwood's (2009) claim that union involvement is crucial if living wage campaigns are to lead to lasting benefits.

Lastly, it is apparent from our interviews that those who took part in the campaign acknowledged and valued the impact of the campaign at several levels. Interviewees pointed to increased visibility in the workplace as one of the positive outcomes of the campaign. Being more aware of rights at work and feeling connected to other communities of practice at the University, such as students and lecturers were other outcomes valued. Thus, even though it is necessary to take cautiously claims to the success of living wage campaigns, it is also important to acknowledge that such success is not limited to wage increment. 


\section{Conclusion}

At the outset of this article we posed two questions: what opportunities existed for migrant workers to organise themselves and what forms these took. This case study suggests that there are opportunities notwithstanding austerity. The living wage campaign was mounted as the university outsourced catering and security services and during a period when university budgets were increasingly under pressure. The campaign at UEL took the form of a broad-based campaign, involving students, academics, trade union members and leaders from the broader community. The success of the campaign, we suggest, is due to the way it avoided the normal channels of industrial relations in the university and engaged the broader community in an issue of the common good. While further research is needed in this area we suggest that it is significant that a community alliance including faith groups was effective is engaging migrant workers with high levels of social capital from membership of faith groups, but limited levels of political experience narrowly defined. Our findings therefore support arguments advanced by Jamoul \& Wills (2008) and Warren (2009) amongst others and support greater engagement of faith groups in the manner pioneered by Citizens UK. This is not to say that all successful living wage campaigns must necessarily take this form but it does offer a model that could be replicated elsewhere in similar circumstances.

Our findings also supported arguments put forward by Holgate (2009) and McBride \& Greenwood (2009) calling on greater engagement of trade unions with community organisations. In our experience both citizen's organisations and trade unions have a vital role to play: the first in engaging migrant workers and the second in consolidating the gains accruing from the living wage. However more researched is needed in this area to show how migrant workers come to participate in campaigns like this and the various stages this participation takes. While trade unions and community organisations work well together at the grassroots level we believe it would be a mistake to ignore substantive philosophical differences between community organising and trade union organising and reduce each approach to a difference of technique as Holgate and Simms have argued (2010). For this reason there is, in our view, a need to rethink the assumptions - conflictual and class-based for the one and communitarian and integrative for the other - underlying each practice if a progressive community-based politics is to emerge. 


\section{Bibliography}

Alinsky, S. (1989) Rules for Radicals - A Practical Primer for Realistic Radicals, New York, Vintage Books.

Chambers, E.T. (2003) Roots for Radicals: Organizing for Power, Action \& Justice New York: Continuum Press

DeFilippis, J; R. Fisher and E. Shragge (2010) Contesting Community: the Limits and Potential of Local Organising (New Brunswick, Rutgers University Press).

Gecan, M. (2002) Going Public: an organiser's guide to citizen action, (New York, Anchor).

Handley, K., Pasick, R., Potter, M., Oliva, G., Goldstein, E. and Nguyen, T. (2010) Community Engaged Research: a Quick-Start Guide for Researchers. University of California, San Francisco. Available at: http://accelerate.ucsf.edu/files/CE/guide for researchers.pdf [last accessed 20/06/2014]

Hearn, J. and M. Bergos (2011) 'Latin American cleaners fight for survival: lessons for migrant activism'. Race \& Class 53 (1), pp.65-82.

Heery, E.; S. Williams and B. Abbott (2012) 'Civil society organizations and trade unions: cooperation, conflict and indifference' Work, Employment and Society 26 (1), pp.145-160.

Holgate, J (2005) 'Organizing migrant workers: a case study of working conditions and unionization in a London sandwich factory' Work, Employment and Society. 19 (3), pp.463-479.

Holgate, J. (2009) 'Contested Terrain: London's Living Wage campaign and the tensions between community and union organizing'. In McBride, J. and Greenwood, I. (eds.) Community Unionism a comparative analysis of concepts and contexts. (Basingstoke: Palgrave MacMillan).

Holgate, J. and Simms, M. (2010) Organising for what?: Where is the debate on the politics of organising?. Work, Employment and Society 24 (1), pp.157-168.

Holgate, J (2013a) Trade Union Involvement in broad-based community organising: a comparative study of London, Sydney \& Seattle. Working Paper no. 14 Centre for Employment Relations Innovation and Change, University of Leeds.

Holgate, J (2013b) Community Organising in the UK: a new approach for Trade Unions? Economic \& Industrial Democracy 0 (0) pp.1-25[01] 
Ivereigh, A. (2010) Faithful Citizens: A Practical Guide to Catholic Social Teaching and Community Organising London Darton, Longman \& Todd.

Jamoul, L. and J. Wills (2008) 'Faith in Politics'. Urban Studies, 45(10), 2035-2056.

Kelly, J. (1998) Retbinking Industrial Relations: mobilization, collectivism and long waves. London;

Routledge.

Kymlica, W. (2002) Contemporary Political Philosophy Oxford: OUP.

Luce, S. (2005) 'Lessons from Living-Wage Campaigns.' Work and Occupations 32(4), pp.423-440.

McAdam, D. (1988) Micromobilization contexts and recruitment to activism. International Social Movement Research, 1, pp.125-154.

McBride, J. and I. Greenwood (eds.) (2009) Community Unionism - a comparative analysis of concepts and contexts. (Basingstoke: Palgrave MacMillan).

Rogers, A.; B. Anderson and N. Clark (2009) Recession, vulnerable workers and immigration: background report. COMPAS, University of Oxford: Oxford.

Trades Union Council Commission on Vulnerable Employment (2008) Hard Work, Hidden Lives: The Full Report of the Commission on Vulnerable Employment. Available online: www.vulnerableworkers.org.uk/2008/05/full...commission.../index.htm

Snarr, C. M. (2007) 'Oh Mary, Don’t You Weep’: progressive religion in the Living Wage movement. Political Theology, 8(3), pp. 269-279.

Symon, G. and J. Crawshaw (2009) Urban labour, voice and legitimacy: economic development and the emergence of community unionism. Industrial relations Journal 10 (2), pp.140-155.

Tilly, C. (1978) From Mobilization to Revolution. New York: McGraw-Hill.

Warren, M.R. (2009) Community Organizing in Britain: The Political Engagement of FaithBased Social Capital. City \& Community 8:2 pp.99-127.

Wills, J. (2008) 'Making class politics possible: organising contract cleaners in London', International Journal of Urban and Regional Research. 2008, 32, 2, 305-24 
Wills, J.; N. Kakpo and R. Begum (2009a) The business case for the living wage: the story of the cleaning service at Queen Mary, The University of London. Available at: http://www.geog.qmul.ac.uk/livingwage/pdf/livingwagereportQM.pdf (accessed 2/4/2012)

Wills, J.; K. Datta, Y. Evans, J. Herbert and C. Mcilwaine (2009b) Religion at work: The role of faith-based organisations in living wage campaigns for immigrant workers in London. The Cambridge Journal of Regions, Economy and Society 2009, 2,3, 443-62.

Wills, J. (2013) Numbers and Money: London living wage research. Available at: http://www.geog.qmul.ac.uk/livingwage/numbersandmoney.html

Wills, J. (2014) 'Engagement' in the Sage Handbook of Progress in Human Geography eds. R. Lee et al (London: Sage publications) 